\title{
Current knowledge in lentil genomics and its application for crop improvement
}

\author{
Shiv Kumar ${ }^{1}{ }^{*}, K_{\text {Karthika Rajendran }}{ }^{*}$, Jitendra Kumar ${ }^{2}$, Aladdin Hamwieh ${ }^{3}$ and Michael Baum ${ }^{4}$ \\ ${ }^{1}$ Biodiversity and Integrated Gene Management Program, International Center for Agricultural Research in the Dry Areas, Rabat, Morocco \\ 2 Division of Crop Improvement, Indian Institute of Pulses Research, Kanpur, India \\ ${ }^{3}$ International Center for Agricultural Research in the Dry Areas, Cairo, Egypt \\ ${ }^{4}$ International Center for Agricultural Research in the Dry Areas, Amman, Jordan
}

\section{Edited by:}

Marta Santalla, Misión Biológica de Galicia - CSIC, Spain

Reviewed by:

Carlos Polanco, Universidad de Leon, Spain

John White Forster, Department of Environment and Primary Industries (Victoria), Australia

\section{*Correspondence:}

Shiv Kumar and Karthika Rajendran, Biodiversity and Integrated Gene Management Program, International Center for Agricultural Research in the Dry Areas, Rabat Office, P.O. Box 6299, Rabat-Instituts, Rabat 10112

Morocco

e-mail: sk.agrawal@cgiar.org;

k.rajendran@cgiar.org
Most of the lentil growing countries face a certain set of abiotic and biotic stresses causing substantial reduction in crop growth, yield, and production. Until-to date, lentil breeders have used conventional plant breeding techniques of selection-recombinationselection cycle to develop improved cultivars. These techniques have been successful in mainstreaming some of the easy-to-manage monogenic traits. However, in case of complex quantitative traits, these conventional techniques are less precise. As most of the economic traits are complex, quantitative, and often influenced by environments and genotype-environment interaction, the genetic improvement of these traits becomes difficult. Genomics assisted breeding is relatively powerful and fast approach to develop high yielding varieties more suitable to adverse environmental conditions. New tools such as molecular markers and bioinformatics are expected to generate new knowledge and improve our understanding on the genetics of complex traits. In the past, the limited availability of genomic resources in lentil could not allow breeders to employ these tools in mainstream breeding program. The recent application of the next generation sequencing and genotyping by sequencing technologies has facilitated to speed up the lentil genome sequencing project and large discovery of genome-wide single nucleotide polymorphism (SNP) markers. Currently, several linkage maps have been developed in lentil through the use of expressed sequenced tag (EST) derived simple sequence repeat (SSR) and SNP markers. These maps have emerged as useful genomic resources to identify quantitative trait loci imparting tolerance to biotic and abiotic stresses in lentil. In this review, the current knowledge on available genomic resources and its application in lentil breeding program are discussed.

Keywords: lentil, molecular markers, single nucleotide polymorphism (SNP), quantitative trait loci (OTL) mapping, marker assisted selection (MAS)

\section{INTRODUCTION}

Lentil (Lens culinaris ssp. culinaris Medikus) is a diploid $(2 \mathrm{n}=2 \mathrm{X}=14)$ self-pollinating crop with a genome size of approximately 4 Gbp (Arumuganathan and Earle, 1991). It provides affordable source of dietary proteins (22-35\%), minerals, fiber, and carbohydrates to poor people and plays a vital role in alleviating malnutrition and micronutrient deficiencies in developing countries. As it exhibits low glycemic index, it is highly recommended by physicians for the people suffering from diabetes, obesity, and cardiovascular diseases (Srivastava and Vasishtha, 2012). In fact, vegetable protein is gaining preference over the animal protein for consumption by the health conscious people in the present day. This could be one of the reasons for increased per capita consumption (Vandenberg, 2009) and fivefold increase in global lentil production (from 0.85 to $4.43 \mathrm{Mt}$ ) during the last five decades, through a $155 \%$ increase in sown area and the doubling of average yields from 528 to $1068 \mathrm{~kg} \mathrm{ha}^{-1}$ (FAOSTAT, 2014). Lentil cultivation often provides rotational benefits to cereal-based cropping systems through biological nitrogen fixation, carbon sequestration, and through effective control of weeds, diseases, and insect pests. It generates livelihood for the small-scale farmers practicing agriculture in the dryland agricultural ecosystems of South Asia, Sub-Saharan Africa, West Asia, and North Africa (Kumar et al., 2013). However, the lentil yields remain low in many developing countries as it is often cultivated as a rainfed crop under difficult edaphic conditions and subjected to terminal drought, heat stress, low soil fertility, and various diseases including ascochyta blight (Ascochyta lentis), fusarium wilt (Fusarium oxysporum f.sp. lentis), anthracnose (Colletotrichum truncatum), stemphylium blight (Stemphylium botryosum), rust (Uromyces viciae-fabae), collar rot (Sclerotiun rolfsii), root rot (Rhizoctonia solani), and white mold (Sclerotinia sclerotiorum) (Kumar et al., 2013; Sharpe et al., 2013). So far, the classical plant breeding approach of selection-recombination-selection has been successful in mainstreaming some of the easy-to-manage monogenic traits in lentil. However, this approach is less precise and time consuming when dealing with traits of breeders' interest which are often quantitative in nature and highly influenced by environment 
and genotype-environment (GE) interaction (Kumar and Ali, 2006). In order to identify, fix, and select superior recombinants more precisely and efficiently, there is a need to integrate biotechnological approaches such as marker assisted selection (MAS) and genetic engineering in lentil breeding program to mainstream new genetic variability in the cultivated gene pool.

The current lentil breeding programs are limited in their ability to implement MAS due to a lack of genomic resources. In comparison to major legume crops such as soybean, common bean, pigeon pea, and chickpea, the pace of development of genomic resources is slow in lentil (Kumar et al., 2014). Large genome size, narrow genetic base, lack of candidate genes, low density linkage map, and the difficulty in identifying beneficial alleles are the main limiting factors in genomics enabled improvement in lentil. Molecular tools have occasionally been used by lentil breeders and geneticists to understand the genetic basis of a few traits related to biotic (ascochyta blight, anthracnose, rust, fusarium wilt, stemphylium blight) and abiotic (drought, frost, cold, boron, salinity) stresses (Kumar et al., 2014). Recent developments in the next generation sequencing (NGS) technologies have facilitated the development of array-based high-throughput (HTP) genotyping platforms with SNP markers. Bett et al. (2014) have carried out large amounts of next-generation sequencing on lentil cultivar, CDC Redberry. An initial draft of $23 x$ coverage produced scaffolds covering over half the genome $(2.7 \mathrm{~Gb}$ of the expected $4.3 \mathrm{~Gb}$ ) and recent additional $125 \mathrm{x}$ coverage is currently being assembled. Gene sequences for several traits of interest were identified using the initial 23x draft assembly and derived SNP markers are now available for MAS in the lentil breeding program (Bett et al., 2014). Besides, the close phylogenetic relationships with the model legumes such as Medicago truncatula and Lotus japonicus have provided ample opportunities for comparative genome mapping and identified putative orthologous gene sequence resources in these genomes (Weller et al., 2012; Kaur et al., 2014). These genomic tools and technologies have opened up new avenues for practicing genomics assisted selection in lentil. There is also a tremendous scope to develop lentil cultivars through reverse genetic approaches. In this context, this review has been made to evaluate the research progress achieved in lentil genomics along with the discussion on future prospective for genetic enhancement.

\section{DEVELOPMENT OF GENOMICS RESOURCES MOLECULAR MARKERS}

The first genetic map of lentil was constructed using morphological and isozyme markers in early 1980's (Zamir and Ladizinsky, 1984; Tadmor etal., 1987). After the discovery of molecular markers starting from the restriction fragment length polymorphism (RFLP), significant progress has been made in molecular marker development and genotyping platforms in lentils. It began with the hybridization based DNA markers such as RFLP (Havey and Muehlbauer, 1989) and moved toward the use of PCR based markers such as random amplified polymorphic DNA (RAPD), amplified fragment length polymorphism (AFLP) and simple sequence repeats (SSR) markers for genotyping. The first comprehensive linkage map with 177 RAPD, AFLP, RFLP, and morphological markers was developed using interspecific recombinant inbred lines (RIL) population of a single cross of L. culinaris $\times$ L. orientalis (Eujayl et al., 1998a). Among the various PCR based markers, SSR markers have made significant contribution to the recent development of lentil genome maps. The first genomic library was constructed from a cultivated accession, ILL5588 using the restriction enzyme Sau3AI (Staphylococcus aureus 3A) and screened with (GT)10, (GA)10, (GC)10, (GAA)8, (TA)10, and (TAA) probes (Hamwieh et al., 2005). Using this library initially a set of 30 highly polymorphic SSR markers were developed. Since this study was aimed at isolating SSRs that are abundant and well distributed in the genome, a non-enriched library was used for screening purposes. Hamwieh et al. (2009) further developed an additional set of 14 SSR markers and used them for genetic diversity analysis of the lentil core set. A set of 122 functional SSR markers have recently been developed using a genomic library enriched for GA/CT motifs for utilization in the lentil breeding program (Verma et al., 2014).

Recently, the PCR-based markers are being rapidly replaced by the DNA chip based markers, particularly with SNPs. SNPs are abundant in nature and common even across legume genomes (Chagne et al., 2007). There are various technologies for evaluation of SNP loci and many of these are amenable to automation for allele calling and data collection. The availability of extensive sequence database has made a new beginning to exploit them as a HTP marker system for genome mapping studies. Recent efforts in re-sequencing alleles to discover SNPs in lentil have facilitated automated high-throughput genotyping platforms (HTP). As a result, SNPs have emerged as potential markers for NGS approaches. About 44,879 SNP markers have been identified in lentil using Illumina Genome Analyzer (Sharpe et al., 2013). Temel et al. (2014) have identified another set of 50,960 SNPs and constructed a SNP based linkage map in lentil. The recent discovery of high-density SNP markers has facilitated the establishment of ultra HTP genotyping technologies such as Illumina GoldenGate (GG), which can accommodate more than 1000 SNPs in GG platforms (Sharpe et al., 2013; Kaur et al., 2014). Since SNP discovery and genotyping require expensive and sophisticated platforms, the development and exploitation of SNP markers is still limited in lentil. There are techniques available to detect SNPs such as allele-specific PCR, single base extension and array hybridization methods. These are cost effective and through the use of allelespecific PCR (KASPar) markers, we can include small to moderate amount of SNPs for any specific application (Fedoruk et al., 2013; Sharpe et al., 2013).

\section{TRANSCRIPTOME ASSEMBLIES}

As the characterization of lentil whole genome is still in progress, transcriptome assemblies provide excellent opportunities to identify expressed sequenced tag (EST) derived SSR and SNP markers and intron-targeted primers (ITP). In the early days, the classical dideoxynucleotide chain termination method of Sanger has been used to sequence cDNA libraries and generate ESTs across various crops. ESTs are short DNA sequences of 150-400 bp from a cDNA clone that correspond to a particular mRNA. Development of HTP functional genomics approaches like serial analysis of gene expression (SAGE) has led to the generation of more 
ESTs. The first EST library was made from a mixture of eight cultivars with varying seed phenotypes (Vijayan et al., 2009). The second cDNA library was prepared from the leaflets of a Canadian cultivar 'Eston' inoculated with Colletotrichum truncatum (Kumar et al., 2014). The cDNA clones corresponding to the ESTs of interest can be used as RFLP or CAPS based markers (Varshney et al., 2005). The EST sequence data also serve the purpose of identifying SSRs and/or SNPs. Before the ESTs, development of SSR and SNP markers was expensive and required high resource laboratories, but presently any user can download them from the database and use some special bioinformatic programs like MISA for SSR detection (Thiel et al., 2003; Varshney et al., 2005) and Snipper for SNP discovery (Kota et al., 2003; Varshney et al., 2005). As on January 2015, there are about 10,341 ESTs available for lentil (NCBI, 2015).

Kaur etal. (2011) carried out transcriptome sequencing of lentil based on the second-generation technology which permits large-scale unigene assembly and SSR marker discovery. They used tissue-specific cDNA samples from six genotypes (Northfield, ILL2024, Indianhead, Digger, ILL6788, and ILL7537) using Roche 454 GS-FLX Titanium technology, and generated c. $1.38 \times 10^{6}$ ESTs. De novo assembly generated 15,354 contigs and 68,715 singletons. Out of huge ESTs produced, 3,470 SNP and EST-SSRs have been identified. Development of genomic resources has become cost effective with the advent of NGS of ESTs. Validation of a subset of 192 EST-SSR markers across a panel of 12 cultivated genotypes showed $47.5 \%$ polymorphism from a set of 2,393 EST-SSR markers developed in lentil (Kaur et al., 2011). In recent times, transcriptome cDNA library sequencing using Illumina GA/GAIIx system has provided a potential alternative. Sharpe et al. (2013) developed 3 -cDNA reads from nine L. culinaris and two L. ervoides accessions using 454 pyrosequencing technology, identified SNPs, selected the sub-set of SNP for the development of a 1536 SNP Illumina GG array and used the array to construct a SNP based genetic map of L. culinaris mapping population. Similarly, Verma et al. (2013) used the short reads obtained from Illumina GAII and developed de novo transcriptome assemblies of lentil, developed SSR markers and utilized them in diversity analysis. Temel et al. (2014) used two lentil cultivars, Precoz and WA8649041 and their RILs using Illumina CASAVA pipelines, detected SNP markers, and generated a SNP based linkage map. As a result of transcriptome sequencing, massive data have been obtained in the form of about 847,824 high quality sequence reads and the transcriptome assemblies with 84,074 unigenes (Sharpe et al., 2013; Verma et al., 2013).

\section{BI-PARENTAL MAPPING POPULATIONS}

Efforts have been made at International Center for Agricultural Research in the Dry Areas (ICARDA) and national programs to develop mapping populations for key traits in lentil (Table 1). RIL populations have been developed from the crosses made between contrasting parents for the traits of interest through single seed descent method. Indian Institute of Pulses Research (IIPR) has recently developed RIL population from a cross between ILL6002 and ILL7663 in order to identify and map early growth vigor genes in lentil. Identification of markers linked to the gene(s)/QTL governing these traits will help in development of
Table 1 | Mapping populations developed for various traits in lentil at International Center for Agricultural Research in the Dry Areas (ICARDA).

\begin{tabular}{|c|c|c|}
\hline Trait & Cross & Population size \\
\hline Drought & ILL 7946 × ILL 7979 & 174 \\
\hline Cold & ILL4605 × ILL 10657 & 153 \\
\hline Earliness & ILL 7115 × ILL 8009 & 150 \\
\hline Rust & ILL 5888 × ILL 6002 & 152 \\
\hline Fusarium wilt & $\begin{array}{l}\text { ILL213 × ILL5883, } \\
\text { Precoz } \times \text { Idleb } 2\end{array}$ & 150 \\
\hline Zn content & $\begin{array}{l}\text { ILL5722 × ILL9888 } \\
\text { ILL9888 × ILL5480 }\end{array}$ & $\begin{array}{l}177 \\
149\end{array}$ \\
\hline Fe content & ILL 9932 × ILL 9951 & 193 \\
\hline
\end{tabular}

genotype having high biomass at early stage. For tagging and mapping of genes of earliness, another mapping population has been developed from a cross between Precoz (Medium early) and L4603 (early) at IIPR, Kanpur, India. Another mapping population segregating for earliness with a cross made between ILL5588 (late flowering) and ILL6005 (early flowering) is available in University of Tasmania, Hobart, TAS, Australia (Weller et al., 2012). It has the loci ELF3 (EARLY FLOWERING 3) which involved in circadian clock function and contribute to reduce the photoperiod response in cultivars to be grown under short season environmental conditions. CSK Himachal Pradesh Agricultural University, Palampur, India has developed RIL populations involving both intra and intersubspecific crosses that differ for rust reaction, drought tolerance, flowering time, plant vigor, shattering tolerance, seed size, and seed weight. Two mapping populations one each with the University of Saskatchewan, Saskatoon, SK, Canada (ILL4605 × ILL5888) and PAU (L-9$12 \times$ FLIP-2004-7L) have been used for molecular mapping (Saha et al., 2010b; Mekonnen et al., 2014). With the rapid generation advancement technology (Mobini etal., 2014) which allows 4-5 generations per year in lentil will boost the development of much needed genetic resources for genomics enabled improvement.

\section{GENETIC LINKAGE MAPS}

In the past, both inter- and intra-specific mapping populations were used for the construction of linkage maps in lentil. The first genetic mapping (linkage analysis) was began by Zamir and Ladizinsky (1984) and the first map comprising DNA based markers was produced by Havey and Muehlbauer (1989). Subsequent maps were published by several workers. With the development of PCR based markers, the number of available markers across the Lens genome increased dramatically (Kumar et al., 2011, 2014). The first extensive map comprised of RAPD, AFLP, RFLP, and morphological markers was constructed using a RIL population from a cross between a cultivated L. culinaris ssp. culinaris cultivar and a L. culinaris ssp. orientalis accession (Eujayl et al., 1998a). As lentil has low level of polymorphism in the cultivated gene pool the inter-varietal linkage maps were developed through the 
use of diverge parents from the wild and cultivated species. However, such molecular maps derived from these populations often result low recombination rate and smaller map size. Intra-specific mapping populations have more practical utility in QTL identification and to tag desirable genes of interest than the previous kind of mapping population. Rubeena et al. (2003) published the first intraspecific lentil map comprising 114 RAPD, inter simple sequence repeat (ISSR) and resistance gene analog (RGA) markers. Rubeena et al. (2006) reported $\mathrm{F}_{2}$ map comprising 72 markers (38 RAPD, 30 AFLP, 3 ISSR, and one morphological) spanning $412.5 \mathrm{cM}$. The first Lens map to include SSR markers was that of Duran et al. (2004). Hamwieh et al. (2005) added 39 SSR and 50 AFLP markers to the map constructed by Eujayl et al. (1998a) to produce a comprehensive Lens map comprising 283 genetic markers covering $715 \mathrm{cM}$. Subsequently, the first lentil map that contained 18 SSR and 79 cross genera ITAP gene-based markers was constructed using a $\mathrm{F}_{5}$ RIL population developed from a cross between ILL5722 and ILL5588 (Phan et al., 2007). The map comprised seven linkage groups (LGs) that varied from 80.2 to $274.6 \mathrm{cM}$ in length and spanned a total of $928.4 \mathrm{cM}$. Gupta et al. (2012a) used 196 markers including new 15 M. truncatula ESTSSR/SSR in a population of 94 RILs produced from a cross between ILL5588 and ILL5722 and generated 11 LGs covering $1156.4 \mathrm{cM}$. An intersubspecific $\mathrm{F}_{2}$ Lens linkage map consisting of 199 PCRbased markers (28 SSRs, 9 ISSRs and 162 RAPDs) mapped on to 11 LGs covering a distance of $3847 \mathrm{cM}$ has been constructed (Gupta et al., 2012b). Recently, population specific linkage maps are developed by Perez de la Vega et al. (2011) and Andeden et al. (2013). A list of comprehensive linkage maps in lentil is provided in Table 2.

\section{COMPARATIVE GENOME MAPPING}

Comparative genome mapping has demonstrated different levels of genome conservation among crop species during the course of evolution (Choi et al., 2004; Zhu et al., 2005). The lentil genome has shown different degrees of synteny with other legume crops (Weeden et al., 1992; Simon and Muehlbauer, 1997; Phan et al., 2007; Choudhary et al., 2009). Development of PCRbased markers has improved transferability of genetic information among species through comparative genomics and has facilitated the establishment of phylogenetic relationship in plants species. Since the availability of SSR markers in lentil is limited, other legumes offer great scope of marker transferability for genomewide coverage. Pandian et al. (2000) observed 5\% transferability of chickpea-specific STMS primers in lentil while Reddy et al. (2010) observed successful amplification of 62\% Trifolium markers followed by Medicago (36\%) and Pisum (25\%). Datta et al. (2011) reported transferability of 19 STMS markers in lentil from common bean, chickpea, pigeon pea, and soybean. The lack of lentil-specific SSR markers propelled the mining and transfer of EST-SSR sequences from the model genome $M$. truncatula to enrich an existing intraspecific lentil genetic map (Gupta et al., 2012a). They published 21 clear and reproducible SSR markers showing polymorphism between parents, Northfield and Digger. EST-based ITAP markers have recently been developed from related crops and applied to lentil. ESTs were compared for phylogenetic distant from M. truncatula, Lupinus albus, and G. max to produce 500 ITAP markers that could be applied to lentil
(Phan et al., 2007). Also, 126 M. truncatula cross-species markers were used to generate comparative genetic maps of lentil and white lupin and macrosyntenic relationships between lentil and field pea was observed. The techniques of comparative genomics provided significant opportunities for genetic diversity studies in lentil. The conserved primers (CPs) based on M. truncatula EST sequences flanking one or more introns were used to sequence amplicons in 175 wild and 133 domesticated lentil accessions (Alo et al., 2011). The analysis of the sequences confirmed that L. nigricans and L. ervoides are well-defined between the species at the DNA sequence level. The availability of draft genome sequences of M. truncatula, L. japonicus, and Glycine max have increased the possibilities of deriving more genomic resources by exploring new molecular markers through bioinformatics platforms which are capable of transfer across the species, belong to the Galegoid clade. Weller et al. (2012) identified two major loci controlling differences in photoperiod response between wild and domesticated pea HR (High response to photoperiod) and ELF3 and identified orthologous gene loci of ELF3 in lentil. Recently, Kaur etal. (2014) made a comparison of the flanking markers SNP_20002998 and SNP_20000246 in lentil for boron tolerance with the Arabidopsis thaliana and M. trucatuala genome sequences and identified candidate genes associated with boron tolerance.

\section{FUNCTIONAL GENOMICS}

Genomic maps are useful to identify gene(s)/QTL responsible for controlling the variation for the underlying trait of interest. Gene cloning approach helps to characterize and reveal the function of the gene/QTL being identified. The knowledge of genes cloned in legumes can facilitate the development of functional markers for MAS. Many functionally known resistance gene analogs (RGA) have been cloned in lentil (Yaish et al., 2004). Likewise the numerous genes coding transcription factors (TFs) are identified in Arabidopsis in a large scale. As the distribution of TF genes does not significantly differ between legume and non-legume species, TF genes have been identified in legumes on the basis of sequence homology with Arabidopsis genes. Using functional genomics approaches, genes expressing differentially in contrasting genotypes can also be identified. Differential gene transcript profiles were assessed among resistant (ILL7537) and susceptible (ILL6002) lentil genotypes at 6, 24, 48, 72, and $96 \mathrm{~h}$ after inoculation with Ascochyta lentis (AL4 isolate; Ford et al., 2007). The non-redundant differentially expressed genes for each accession and time points were hierarchically clustered using Euclidean metrics. In total, 25 differentially expressed sequences were up-regulated and 56 down-regulated in ILL7537 whereas 26 were up-regulated and 44 down-regulated in ILL6002. Several candidate defense genes were characterized from lentil including a $b$-1, 3-glucanase, a pathogenesis-related protein from the Bet v I family, a pea disease resistance response protein 230 (DRR230-a), a disease resistance response protein (DRRG49-C), a PR4 type gene and a gene encoding an antimicrobial SNAKIN2 protein, all of which have been fully sequenced. Several TFs were also recovered at $6 \mathrm{~h}$ after inoculation and future aim is to further biologically characterize these and earlier responses to gain a comprehensive understanding of the key pathogen recognition and defense pathways to 
Table 2 | List of molecular linkage maps developed in lentil.

\begin{tabular}{|c|c|c|c|c|c|c|}
\hline $\begin{array}{l}\text { Type of } \\
\text { population }\end{array}$ & Parents & $\begin{array}{l}\text { Population } \\
\text { size }\end{array}$ & No. of loci & Type of markers & $\begin{array}{l}\text { Map length } \\
\text { (cM) }\end{array}$ & Reference \\
\hline$F_{2}$ & $\begin{array}{l}\text { L. culinaris ssp. } \\
\text { culinaris } \times \text { L.c.ssp. orientalis }\end{array}$ & & 10 & Isozymes & - & Zamir and Ladizinsky (1984) \\
\hline RIL & $\begin{array}{l}\text { L.c.ssp. orientalis } \times \text { L. } \\
\text { culinaris ssp. culinaris }\end{array}$ & 86 & 177 & $\begin{array}{l}\text { RAPD, AFLP, RFLP, and } \\
\text { morphological markers }\end{array}$ & 1073 & Eujayl et al. (1998a) \\
\hline $\mathrm{F}_{2}$ & $\begin{array}{l}\text { L. culinaris ssp. } \\
\text { culinaris } \times \text { L.c.ssp. orientalis }\end{array}$ & 113 & 200 & $\begin{array}{l}\text { RAPD, ISSR, AFLP, SSR, } \\
\text { CAPS, SRAPS, and } \\
\text { morphological markers }\end{array}$ & 2234 & $\begin{array}{l}\text { Duran etal. (2004), Fratini } \\
\text { etal. (2004), de la Puente } \\
\text { etal. (2013) }\end{array}$ \\
\hline RIL & Eston $\times$ PI 320937 & 94 & 207 & AFLP, RAPD, and SSR & 1868 & Tullu et al. $(2006,2008)$ \\
\hline RIL & Precoz $\times$ WA 8649041 & 94 & 166 & $\begin{array}{l}\text { AFLP, ISSR, RAPD, and } \\
\text { morphological markers }\end{array}$ & 1396 & Tanyolac et al. (2010) \\
\hline RIL & ILL $6002 \times$ ILL 5888 & 206 & 139 & $\begin{array}{l}\text { SSR, RAPD, SRAP, and } \\
\text { morphological markers }\end{array}$ & 1565 & Saha et al. (2010a, 2013) \\
\hline RIL & WA8649090 $\times$ Precoz & 106 & 130 & RAPD, ISSR, and AFLP & 1192 & Kahraman etal. $(2004,2010)$ \\
\hline RIL & ILL5722 × ILL5588 & 94 & 211 & RAPD, ISSR, ITAP, and SSR & 1392 & Gupta etal. (2012a) \\
\hline $\mathrm{F}_{2}$ & L830 × ILWL77 & 114 & 199 & SSR, ISSR, and RAPD & 3843 & Gupta et al. (2012b) \\
\hline RIL & CDC Robin × 964a-46 & 139 & 561 & $\begin{array}{l}\text { SNP, SSR, and seed color } \\
\text { genes }\end{array}$ & 697 & $\begin{array}{l}\text { Fedoruk et al. (2013), Sharpe } \\
\text { etal. (2013) }\end{array}$ \\
\hline
\end{tabular}

A. lentis in lentil. Also, the full-length gene sequences will be used in transgenic studies to further characterize their functions. Microarrays play important role in identifying gene networks underlying the expression of important plant traits. A DNA pulse chip made up of 565 ESTs from a chickpea cDNA library enriched for reaction to A. rabiei, 156 ESTs from a Lathyrus cDNA library enriched for reaction to $A$. pinodes and 41 lentil ESTs and RGAs from the GenBank database (Coram and Pang, 2005) was employed to study expression profiles for ascochyta blight resistant (ILL7537) and susceptible (ILL6002) cultivars (Mustafa et al., 2006).

\section{APPLICATION OF GENOMIC RESOURCES FOR LENTIL IMPROVEMENT GENETIC FINGER PRINTING}

Genetic diversity analysis has been studied among a set of cultivated and wild lentils using various molecular marker system and genetic materials. Earlier studies have used RFLP, AFLP, and RAPD markers to assess genetic diversity and phylogenetic analyses within and among Lens species (Havey and Muehlbauer, 1989; Aboelwafa et al., 1995; Sharma et al., 1995, 1996; Ahmad and McNeil, 1996; Ford etal., 1997) and gene mapping (Eujayl et al., 1998b; Tullu et al., 2003; Duran et al., 2004; Kahraman et al., 2004; Hamwieh et al., 2005). As a part of the CGIAR's Generation Challenge Program (GCP), ICARDA has identified a composite collection of lentil germplasm and characterized them by using SSR markers. ICARDA holds the largest global collection of lentil with $>11,000$ accessions. From this collection, a global composite collection of 960 accessions (Table 3) representing landraces, wild relatives, elite breeding lines, and cultivars was established (Furman, 2006). The results indicated two major clusters separating south Asia (Nepal, India, Pakistan, and Afghanistan) from the Middle East and western countries (Figure 1). The major output of this study was a reference set which represents around 15\% (135 accessions) of the global composite collection representing all the geographical regions. This set has been phenotyped for different biotic and abiotic stresses, and emerged as a useful genetic resource to start with (Kumar et al., 2014). Recently, a set of SSR 
Table 3 | Composition of core germplasm representing $\mathbf{1 0} \%$ of the global lentil collection by ICARDA.

\begin{tabular}{|c|c|c|c|c|c|}
\hline Country & No. of accessions & Country & No. of accessions & Country & No. of accessions \\
\hline Afghanistan & 30 & Germany & 10 & Romania & 2 \\
\hline Algeria & 11 & Guatemala & 1 & Saudi Arabia & 1 \\
\hline Argentina & 6 & Hungary & 3 & Scg & 4 \\
\hline Bangladesh & 6 & Iraq & 11 & Sudan & 2 \\
\hline Belgium & 1 & Italy & 6 & Syria & 70 \\
\hline Brazil & 2 & Jordan & 46 & Tajikistan & 5 \\
\hline Breeding & 35 & Lebanon & 9 & Tunisia & 8 \\
\hline China & 1 & Morocco & 14 & US & 10 \\
\hline Colombia & 3 & Nepal & 28 & Unknown & 7 \\
\hline Croatia & 1 & Netherlands & 1 & Uruguay & 1 \\
\hline Cyprus & 9 & Norway & 1 & Uzbekistan & 2 \\
\hline Czech Republic & 6 & Pakistan & 27 & Yemen & 12 \\
\hline Egypt & 25 & $\mathrm{Pal}$ & 4 & Yugoslavia & 2 \\
\hline Ethiopia & 49 & Poland & 4 & Sum & 960 \\
\hline France & 5 & Portugal & 5 & & \\
\hline
\end{tabular}

markers was used to study the genetic diversity of lentil mini core set. The mini core collection comprised 109 accessions from 15 countries representing 57 cultigens (including 18 breeding lines) from 8 countries to 52 wild accessions (L. culinaris ssp. orientalis, L. culinaris ssp. tomentosus and L. culinaris ssp. odemensis) from 11 countries. The total alleles detected across the SSR loci were 182 , with a mean of 13 alleles per locus. Wild accessions were rich in allelic variation (151 alleles) compared to cultigens (114 alleles). The genetic diversity index for the SSR loci in the wild accessions ranged from 0.16 (SSR28 in L. culinaris ssp. odemensis) to 0.93 (SSR66 in L. culinaris ssp. orientalis) with a mean of 0.66 , while in the cultigens, genetic diversity varied between 0.03 (SSR28) and 0.87 (SSR207) with a mean of 0.65. Cluster analysis indicated two major clusters (Figure 2), mainly one with the cultigens and the other with wild accessions (Hamwieh et al., 2009). The recent techniques of comparative genomics also provided significant opportunities for genetic diversity studies in lentil. The CPs based on M. truncatula EST sequences flanking one or more introns were used to sequence amplicons in 175 wild and 133 domesticated accessions. This analysis of the sequences confirmed that $L$. nigricans and L. ervoides are well-defined species at the DNA sequence level. L. culinaris ssp. orientalis is the progenitor of domesticated lentil, L. culinaris ssp. culinaris, but a more specific area of origin can be suggested in southern Turkey. The study detected the divergence, following domestication, of the domesticated gene pool into overlapping large seeded (megasperma) and small-seeded (microsperma) groups and observed that lentil domestication led to a loss of genetic diversity of approximately $40 \%$ (Alo et al., 2011).

\section{HYBRID TESTING}

Making crosses between diverse parents is difficult in practice in lentil because of very small flowers leading to increase the chances of selfing. In addition to this, differentiating $F_{1}$ plants from selfed ones also becomes difficult due to low phenotypic diversity between the parents. Hence molecular markers have been found very useful to detect the hybridity of $\mathrm{F}_{1}$ plants in lentil. Solanki et al. (2010) used molecular markers in lentil and detected only $21 \%$ plants as true hybrids. These results suggest that molecular markers can reduce the time and money required to grow a population from selfed or admixed plants and increase the efficiency of plant breeders in selection of recombinant plants.

\section{MARKER ASSISTED SELECTION}

Molecular markers linked to desirable gene(s)/QTL have been reported for marker-assisted selection in lentil (Table 4). Morphological markers viz., cotyledon $(Y c)$, anthocyanin in stem $(G s)$, pod indehiscence $(P i)$, seed coat pattern $(S c p)$, flower color $(W)$, radiation frost tolerance locus $(R f)$, early flowering $(S n)$, and ground color of the seed $(G c)$ were mapped as qualitative markers because they exhibited monogenic dominant mode of inheritance (Eujayl et al., 1998a; Duran etal., 2004; Hamwieh et al., 2005; Tullu et al., 2008). Further analysis for the association between DNA markers and Fusarium wilt resistance $(\mathrm{Fw})$ 


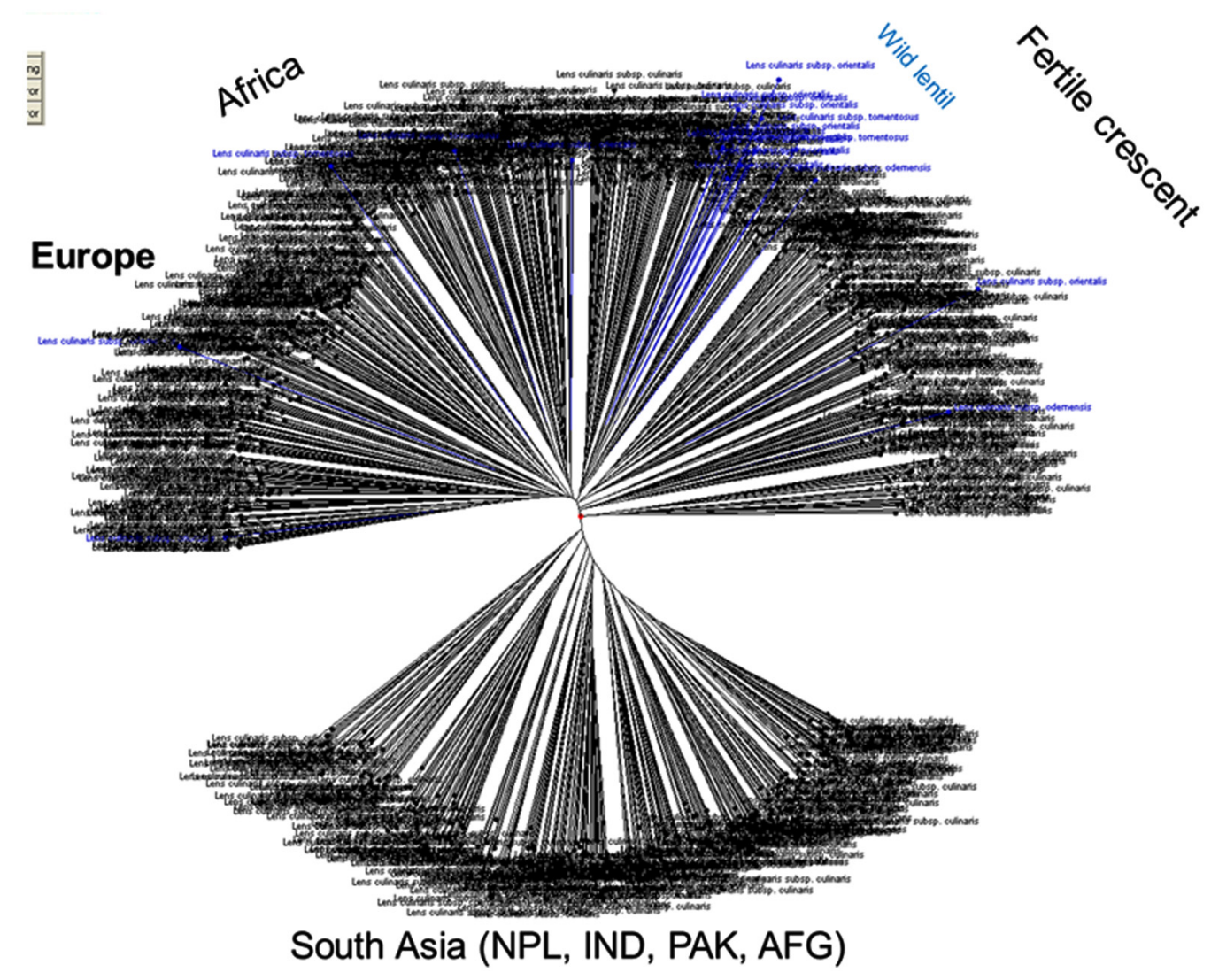

FIGURE 1 | Cluster analysis of core ICARDA lentil (both wild and cultivated) germplasm collections using 22 SSR markers. The results indicated two major clusters separating south Asia (Nepal, India, Pakistan and Afghanistan) from the Middle East and western countries (adapted from Kumar et al., 2014).

gene was confirmed (Eujayl et al., 1998b; Hamwieh et al., 2005). However, only SSR59-2B was closely linked with Fw at $19.7 \mathrm{cM}$ (Hamwieh et al., 2005). Anthracnose disease resistance (Lct-2) was mapped by Tullu et al. (2003). To date, quantitatively inherited traits have been mapped by Duran et al. (2004) who detected five QTL each for the height of the first ramification and flowering time, three for plant height, seven for pod dehiscence, and one each for shoot number and seed diameter. Five and four QTL were identified for winter survival and winter injury, using a RIL population of 106 lines derived from WA8649090 × Precoz (Kahraman et al., 2004). In this study, experiments were conducted at multiple locations and only one of five QTL was expressed in all environments. Mapping of Ascochyta blight resistance using an $\mathrm{F}_{2}$ population derived from ILL7537 $\times$ ILL6002 identified three QTL accounting for 47\% (QTL-1 and QTL-2) and 10\% (QTL3) of disease variation. Recently, QTL conferring resistance to Stemphylium blight and rust diseases using RIL populations were identified in lentil (Saha et al., 2010a,b). Though the use of $F_{2}$ populations in identification of QTL has been done widely in lentil, their use in marker-trait analysis has led to identification of only major QTL. Thus, several minor QTL were overlooked in such populations and identification of environmental responsive QTL was difficult. Because quantitative traits are influenced by both genetic and environmental effects, RILs or near isogenic lines
(NILs) are more suitable populations to accurately dissect their components. For ascochyta blight, three QTL each were detected for resistance at seedling and pod/maturity stages (Gupta et al., 2012a). Together these accounted for 34 and $61 \%$ of the total estimated phenotypic variation and demonstrated that resistance at different growth stages is potentially conditioned by different genomic regions. Kaur et al. (2014) identified QTL for boron tolerance in Cassab $\times$ ILL2024 mapping population. Both simple interval mapping (SIM) and composite interval mapping (CIM) confirmed the presence of QTL in LG4.2 between SNP_20002998 and SNP_20000246. The flanking markers identified may be useful for MAS and pyramiding of potentially different resistance genes into elite backgrounds that are resistant throughout the cropping season. While using QTL pyramiding approach Taran et al. (2003) identified lines with combined resistance to ascochyta blight resistance $\left(A b R 1\right.$ and rall) and Anthracnose $\left(\right.$ OPO6 $\left._{1250}\right)$ in CDC Robin and 964a-46 RIL population for developing cultivars resistance to both ascochyta blight and anthracnose in lentil.

\section{GENE-TRAIT ASSOCIATION ANALYSIS USING NATURAL DIVERSE POPULATION}

Bi-parental mapping approach causes more chances for segregation distortion through favoring of one parental allele over another. Also, the molecular markers which can be polymorphic 


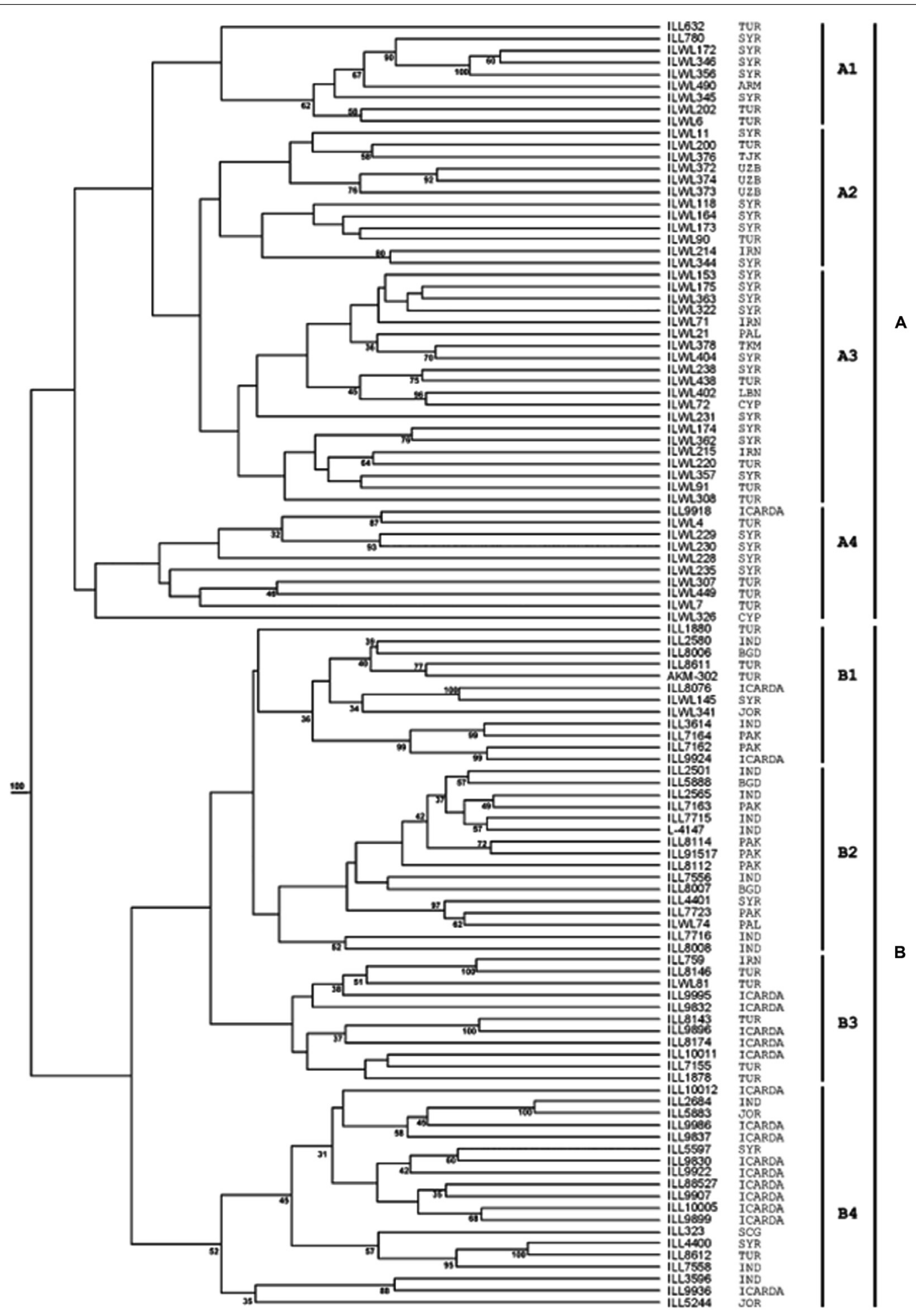

0,1

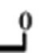

FIGURE 2 | Cluster analysis of ICARDA lentil (both wild and cultivated) mini-core set lentil accessions using 14 SSR markers. The groups are denoted on the right side as $A$ or $B$, and the sub-groups as $A 1, A 2, A 3, A 4$, B1, B2, B3, and B4. The origins of 109 lentil accessions are listed closed to the genotype numbers. Bootstrap values of above $30 \%$ are indicated the nodes. The abbreviations of the countries: Bangladesh (BGD), India (IND), Iran (IRN), Jordan (JOR), Pakistan (PAK), Syria (SYR), Turkey (TUR), Serbia \& Montenegro (SCG), Palestine (PAL), Armenia (ARM), Cyprus (CYP), Uzbekistan (UZB), Tajikistan (TJK), Turkmenistan (TKM), Lebanon (LBN) (adapted from Hamwieh et al., 2009; Kumar et al., 2014). 
Table 4 | Molecular markers linked to desirable genes/OTL for marker-assisted selection in lentil.

\begin{tabular}{|c|c|c|c|c|}
\hline Traits & Mapping population & Marker linked with the QTL & $\begin{array}{l}\text { Phenotypic variation } \\
\text { explained by the OTL (\%) }\end{array}$ & Reference \\
\hline \multirow{5}{*}{$\begin{array}{l}\text { Ascochyta blight } \\
\text { resistance }\end{array}$} & ILL5588 × ILL6000 & RAPD & 90 & Ford et al. (1999) \\
\hline & ILL5588 × ILL7537 and & RAPD, AFLP, and ISSR & Up to 50 & Rubeena et al. (2006) \\
\hline & ILL7537 × ILL6002 & & & \\
\hline & Eston $\times$ PI320937 & AFLP and RAPD & 41 & Tullu et al. (2006) \\
\hline & $\begin{array}{l}\text { NorthWeld (ILL5588) × Digger } \\
(\text { ILL5722) }\end{array}$ & ITAP, SSR, and ISSR & Up to 61 & Gupta et al. (2012a) \\
\hline Earliness & Eston $\times$ PI320937 & RAPD, AFLP, and SSR & $37-46$ & Tullu et al. (2008) \\
\hline \multirow[t]{2}{*}{ Plant height } & Eston $\times$ PI320937 & RAPD, AFLP, and SSR & $31-40$ & Tullu et al. (2008) \\
\hline & $\begin{array}{l}\text { L. culinaris ssp. } \\
\text { culinaris } \times \text { L.c.ssp. orientalis }\end{array}$ & $\begin{array}{l}\text { RAPD, ISSR, AFLP, SSR, and } \\
\text { morphological markers }\end{array}$ & 38.2 & Fratini et al. (2007) \\
\hline Branches at the & L. culinaris ssp. & RAPD, ISSR, AFLP, SSR, and & 91.7 & Fratini et al. (2007) \\
\hline first node & culinaris $\times$ L.c.ssp. orientalis & morphological markers & & \\
\hline Total number of & L. culinaris ssp. & RAPD, ISSR, AFLP, SSR and & 54 & Fratini et al. (2007) \\
\hline branches & culinaris $\times$ L.c.ssp. orientalis & morphological markers & & \\
\hline Height at the first & L. culinaris ssp. & RAPD, ISSR, AFLP, SSR, and & 33.3 & Fratini et al. (2007) \\
\hline node & culinaris $\times$ L.c.ssp. orientalis & morphological markers & & \\
\hline Flowering time & $\begin{array}{l}\text { L. culinaris ssp. } \\
\text { culinaris } \times \text { L.c.ssp. orientalis }\end{array}$ & $\begin{array}{l}\text { RAPD, ISSR, AFLP, SSR, and } \\
\text { morphological markers }\end{array}$ & 90.4 & Fratini et al. (2007) \\
\hline Pod dehiscence & $\begin{array}{l}\text { L. culinaris ssp. } \\
\text { culinaris } \times \text { L.c.ssp. orientalis }\end{array}$ & $\begin{array}{l}\text { RAPD, ISSR, AFLP, SSR, and } \\
\text { morphological markers }\end{array}$ & 81.3 & Fratini et al. (2007) \\
\hline Seed weight & $\begin{array}{l}\text { L. culinaris ssp. } \\
\text { culinaris } \times \text { L.c.ssp. orientalis }\end{array}$ & $\begin{array}{l}\text { RAPD, ISSR, AFLP, SSR, and } \\
\text { morphological markers }\end{array}$ & 18.2 & Fratini et al. (2007) \\
\hline Seed diameter & $\begin{array}{l}\text { L. culinaris ssp. } \\
\text { culinaris } \times \text { L.c.ssp. orientalis }\end{array}$ & $\begin{array}{l}\text { RAPD, ISSR, AFLP, SSR, and } \\
\text { morphological markers }\end{array}$ & 37 & Fratini et al. (2007) \\
\hline Winter hardiness & WA8649090 × Precoz & RAPD, ISSR, and AFLP & 20.45 & Kahraman et al. (2010) \\
\hline $\begin{array}{l}\text { Cotyledon color } \\
\text { class }\left(Y_{C}\right)\end{array}$ & CDC Robin × 964a-46 & SNP, SSR, and seed color loci & 23 & Fedoruk et al. (2013) \\
\hline Seed thickness & CDC Robin × 964a-46 & SNP, SSR, and seed color loci & 8.4 & Fedoruk etal. (2013) \\
\hline Seed diameter & CDC Robin × 964a-46 & SNP, SSR, and seed color loci & Up to 60 & Fedoruk etal. (2013) \\
\hline Seed plumpness & CDC Robin × 964a-46 & SNP, SSR, and seed color loci & Up to 50 & Fedoruk et al. (2013) \\
\hline \multirow{3}{*}{$\begin{array}{l}\text { Days to } 50 \% \\
\text { flowering }\end{array}$} & CDC Robin × 964a-46 & SNP, SSR, and seed color loci & Up to 34 & Fedoruk etal. (2013) \\
\hline & & & & \\
\hline & ILL6002 × ILL5888 & SSR, SRAP, RAPD & 24.2 & Saha et al. (2013) \\
\hline $\begin{array}{l}\text { Hundred seed } \\
\text { weight }\end{array}$ & ILL6002 × ILL5888 & SSR, SRAP, RAPD & 17.5 & Saha et al. (2013) \\
\hline Plant height & ILL6002 × ILL5888 & SSR, SRAP, RAPD & 15.3 & Saha et al. (2013) \\
\hline Seed diameter & ILL6002 × ILL5888 & SSR, SRAP, RAPD & 32.6 & Saha et al. (2013) \\
\hline Stemphylium & ILL6002 × ILL5888 & SSR, SRAP, RAPD & 46 & Saha et al. (2010a) \\
\hline blight resistance & & & & \\
\hline Boron tolerance & Cassab × ILL2024 & SNP & 71 & Kaur et al. (2014) \\
\hline
\end{tabular}

within the interspecific populations might not be polymorphic at the species level as genetic background affects their utility in MAS process. Association mapping is an alternative approach that can address these shortcomings of bi-parental linkage mapping.
While using historical recombination in natural populations, landraces, breeding material and varieties, association mapping does marker-trait association and identifies QTL with high resolution. There are two different types of association mapping which can 
be done on any crop species: genome-wide association studies (GWAS) and candidate gene association mapping. However, to date there are very few reported studies about association mapping in lentil. It is mainly due to the lack of genomic resources available for lentil. After identification of 1536-SNP Illumina GG array (Lc1536) by Sharpe et al. (2013), the Lc1536 array was used in GWAS. The linkage disequilibrium (LD) in lentil may occur similar to that in barley, soybean, and M. truncatula (Branca et al., 2011). Fedoruk et al. (2013) used association mapping in lentil to identify QTL for seed size and seed shape. As the properly designed association panels have a greater frequency of alleles encompassing the genetic variation of a crop, it can greatly facilitate to save time and cost while performing MAS in lentil.

\section{GENETIC TRANSFORMATIONS}

Transgenic approach uses functional genes which are not available within the crossable gene pool. Thus cloned genes are important genomic resources for making genetic manipulation through transformation. Commonly, the particle bombardment and the Agrobacterium tumefaciens infection methods have been used to introduce genes with novel functions. With the explosion of sequence information available in the databases, transformation systems have also become useful tools to study gene function via RNA interference 'knockout,' T-DNA insertion or transforming a genotype lacking a particular gene. Thus a robust, reproducible and efficient transformation system combined with a protocol to regenerate complete fertile plants from transformed cells is essential to fully study plant gene functions.

Following the initial report of shoot regeneration (Bajaj and Dhanju, 1979) from apical meristems, it has been achieved routinely with different explants such as apical meristems (Bajaj and Dhanju, 1979), stem nodes (Polanco et al., 1988; Singh and Raghuvanshi, 1989; Ahmad et al., 1997), cotyledonary node (Warkentin and McHughen, 1992), epicotyls (Williams and McHughen, 1986), decapitated embryo, embryo axis and immature seeds (Polanco and Ruiz, 2001), and cotyledonary petioles (Khawar and Özcan, 2002). The induction of functional roots on in vitro-developed shoots has been the major challenge in lentil micro propagation. The difficulty to induce roots is thought to be associated with the use of cytokinin to obtain multiple shoots from the initial explants (Mohamed et al., 1992). Among the several studies conducted on root induction from shoots, Fratini and Ruiz (2003) reported 95\% rooting efficiency from nodal segments cultured in an inverted orientation in media with $5 \mu \mathrm{M}$ indole acetic acid (IAA) and $1 \mu \mathrm{M}$ kinetin (KN). Sarker et al. (2003) reported 30\% rooting efficiency on MS medium supplemented with $25 \mathrm{mg} / \mathrm{l}$ indole butyric acid (IBA).

To date, transformation of lentil has been reported through A. tumefaciens-mediated gene transfer (Lurquin et al., 1998) and biolistic transformation including electroporation (Chowrira etal., 1996) and particle bombardment (Gulati etal., 2002; Mahmoudian et al., 2002). Warkentin and McHughen (1992) reported the susceptibility of lentil to A. tumefaciens and later evaluated a number of explant types including shoot apices, epicotyl, root, cotyledons, and cotyledonary nodes. All explants showed transient $b$-glucuronidase (GUS) expression at the wound sites except cotyledonary nodes, which were subsequently transformed by Sarker et al. (2003). Oktem et al. (1999) reported the first transient and stable chimeric transgene expression on cotyledonary lentil nodes using particle bombardment. Gulati etal. (2002) reported regeneration of the first fertile transgenic lentil plants on MS medium with $4.4 \mu \mathrm{M}$ benzyladenine (BA), $5.2 \mu \mathrm{M}$ gibberellic acid (GA3), and chlorsulfuron ( $5 \mathrm{nM}$ for 28 days and $2.5 \mathrm{nM}$ for the rest of the culture period), followed by micrografting and transplantation in soil. The first successful work was reported by Barton et al. (1997), using pCGP1258 plasmid construct on four lentil genotypes. Khatib et al. (2007) have developed herbicideresistant lentil through $A$. tumefaciens mediated transformation. This was achieved with the same plasmid construct pCGP1258, harboring the bar gene conferring resistance to the herbicide glufosinate ammonium that was transformed using A. tumefaciens strain AgL0. Three lentil lines, ILL5582, ILL5883, and ILL5588, were used and a high selection pressure of $20 \mathrm{mg} / \mathrm{l}$ of glufosinate was applied to the explants for 18 weeks. Surviving shoots were subsequently grafted onto non-transgenic rootstock and plantlets were transferred to soil and acclimatized. The presence of the transgene was confirmed by PCR and the gene function was confirmed via herbicide application. Recently, Akcay et al. (2009) reported the production of transgenic lentil plants via Agrobacterium-mediated transformation and the stable transmission of the nptII and gusA genes in the subsequent generations. However, these studies were mostly confined to establish transformation techniques rather than the introduction of genes into improved varieties. Khatib et al. (2011) reported for the first time the introduction of the DREB1A gene into lentil for enhancing drought and salinity tolerance. The PCR results confirmed the insertion and stable inheritance of the gene of interest and bar marker gene in the plant genome. The Southern blot analysis revealed integration of a single copy of the transgene. The DREB1A gene driven by $\mathrm{rd} 29 \mathrm{~A}$ promoter transcribed in the transgenic plants by inducing salt stress in form of sodium chloride solution. The results showed that mRNA was accumulated and thus the DREB1A gene was expressed in the transgenic plants.

\section{FUTURE PERSPECTIVES}

Application of MAS is still limited in lentil. The NGS technology has opened up new opportunity for the fast development of sequence based markers. Access to HTP genotyping and sequencing technologies is expected to speed up the genetic gain across the target environments in lentil. These developments ultimately will increase the utilization of genomic resources in genetic improvement of lentil and will lead fast track development of improved cultivars. Further, increasing number of re-sequencing database in coming days will allow identification of more SNPs and consequently, HTP cost-effective genotyping assays using only informative SNPs would become available for the development of high density linkages for MAS. Recent collaborations among the labs in Canada, Australia, Czech Republic, Spain, USA, ICARDA, and Kenya will facilitate further assembly and annotation of the draft genome, as well as add to the growing database of genetic diversity in the global lentil germplasm. This will include use of long reads based on PacBio sequencing to assemble smaller scaffolds into larger assemblies. Key 
mapping populations would be genotyped using GBS technology to anchor scaffolds into chromosomal pseudo-molecules and selected lentil genotypes need to be re-sequenced to reveal the genomic diversity in lentil germplasm and provide a road map for future breeding activities. These advances also simultaneously encourage the lentil breeders to develop specialized mapping population such as nested association mapping (NAM) and multi-parents advanced generation inter-cross (MAGIC) populations to generate the genome-wide allelic and haplotype data. Likewise, non-transgenic techniques such as target-induced local lesion in genomes (TILLING) and RNA interference (RNAi) also have demonstrated potential scope for lentil improvement. TILLING has significantly contributed to the understanding of function of pea subtilase (SBT1.1) and tendril-less $(t l)$ genes which control the seed size and tendril formation (D'Erfurth etal., 2012). At ICARDA, mutagenic lentil populations have been recently developed using the mutagen, ethyl methane sulfonate (EMS) in order to identify any point and knock-out mutations for tendril formation and other traits such as pod shattering, herbicide tolerance and Orobanche tolerance. Likewise the other non-transgenic approaches including RNAi technology and virus-induced gene silencing (VIGS) will help understand the molecular mechanisms of biological nitrogen fixation in lentil. The coming years would provide more opportunities to integrate $\mathrm{GAB}$ tools in the conventional breeding program. At the same time, more concerted efforts are required to develop other genomic resources such as BAC libraries and other transcriptome assemblies.

\section{CONCLUSION}

Identifying the desired variability for target traits, utilizing the variability in breeding programs, and selecting and advancing the targeted recombinants are the major steps in a breeding program. Conventional breeding approaches are helpful to utilize the available genetic variability in the cultivated germplasm, resulting in the development of several red and yellow cotyledon varieties of lentil with tolerance/resistance to cold, ascochyta blight, rust, and wilt. In the last decade, several linkage maps have been developed and QTL/genes identified for the traits of interest in lentil. This has opened up the scope for mainstreaming genomics enabled improvement in lentil breeding programs. It will get further boost once the draft genome sequence and resequencing of the reference set of lentil is completed.

\section{ACKNOWLEDGMENTS}

The authors acknowledge CGIAR Research Program on Grain Legumes for providing financial and research support.

\section{REFERENCES}

Aboelwafa, A., Murai, K., and Shimada, T. (1995). Intra-specific and inter-specific variations in Lens revealed by RAPD markers. Theor. Appl. Genet. 90, 335-340.

Ahmad, M., Fautrier, A. G., McNeil, D. L., Hill, G. D., and Burritt, D. J. (1997). In vitro propagation of Lens species and their $\mathrm{F}_{1}$ interspecific hybrids. Plant Cell Tiss. Org. Cult. 47, 169-176. doi: 10.1007/bf02318954

Ahmad, M., and McNeil, D. L. (1996). Comparison of crossability, RAPD, SDSPAGE and morphological markers for revealing genetic relationships within and among Lens species. Theor. Appl. Genet. 93, 788-793. doi: 10.1007/bf00224077

Akcay, U. C., Mahmoudian, M., Kamci, H., Yucel, M., and Oktem, H. A. (2009). Agrobacterium tumefaciens-mediated genetic transformation of a recalcitrant grain legume, lentil (Lens culinaris Medik). Plant Cell Rep. 28, 407-417. doi: 10.1007/s00299-008-0652-4

Aldemir, S. B., Sever, T., Ates, D., Yagmur, B., Kaya, H. B., Temel, H. Y., et al. (2014). "QTL mapping of genes controlling Fe uptake in lentil (Lens culinaris L.) seed using recombinant inbred lines," in Proceedings of the Plant and Animal Genome Conference XXII P3360, San Diego, CA.

Alo, F., Furman, B. J., Akhunov, E., Dvorak, J., and Gepts, P. (2011). Leveraging genomic resources of model species for the assessment of diversity and phylogeny in wild and domesticated lentil. J. Hered. 102, 315-329. doi: 10.1093/jhered/esr015

Andeden, E. E., Derya, M., Baloch, F. S., Kilian, B., and Ozkan, H. (2013). "Development of SSR markers in lentil," in Proceedings of Plant and Animal Genome Conference XXI P0351, San Diego, CA.

Arumuganathan, K., and Earle, E. D. (1991). Nuclear DNA content of some important plant species. Plant Mol. Biol. Rep. 9, 208-218. doi: 10.1007/BF02672069

Bajaj, Y. P. S., and Dhanju, M. S. (1979). Regeneration of plants from apical meristem tips of some legumes. Curr. Sci. 48, 906-907.

Barton, J., Klyne, A., Tennakon, D., Francis, C., and Hamblin, J. (1997). “Development of a system for gene transfer to lentils," in Proceedings of International Food Legume Research Conference III, Adelaide, SA.

Bett, K., Ramsay, L., Sharpe, A., Cook, D., Penmetsa, R. V., Verma, N., et al. (2014). "Lentil genome sequencing: establishing a comprehensive platform for molecular breeding," in Proceedings of International Food Legumes Research Conference (IFLRC-VI) and ICCLG-VII (Saskatoon, SK: Crop Development Center), 19.

Branca, A., Paape, T. D., Zhou, P., Briskine, R., Farmer, A. D., Mudge, J., et al. (2011). Whole genome nucleotide diversity, recombination and linkage disequilibrium in the model legume Medicago truncatula. Proc. Nat. Acad. Sci. U.S.A. 108, E864-E870. doi: 10.1073/pnas.1104032108

Chagne, D., Carlisle, C. M., Blond, C., Volz, R. K., Whitworth, C. J., Oraguzie, N. C., et al. (2007). Mapping a candidate gene (MdMYB10) for red flesh and foliage colour in apple. BMC Genomics 8:212. doi: 10.1186/1471-2164-8-212

Choi, H. K., Mun, J. H., Kim, D. J., Zhu, H. Y., Baek, J. M., Mudge, J., et al. (2004). Estimating genome conservation between crop and model legume species. Proc. Natl. Acad. Sci. U.S.A. 101, 15289-15294. doi: 10.1073/pnas/04022 51101

Choudhary, S., Sethy, N. K., Shokeen, B., and Bhatia, S. (2009). Development of chickpea EST-SSR markers and analysis of allelic variation across related species. Theor. Appl. Genet. 118, 591-608. doi: 10.1007/s00122-008-0923-z

Chowrira, G. M., Akella, V., Fuerst, P. E., and Lurquin, P. F. (1996). Transgenic grain legumes obtained by in planta electroporation-mediated gene transfer. Mol. Biotechnol. 5, 85-96. doi: 10.1007/bf02789058

Coram, T. E., and Pang, E. C. K. (2005). Expression profiling of chickpea genes differentially regulated during a resistance response to Ascochyta rabiei. Plant Biotechnol. J. 4, 647-666. doi: 10.1111/j.1467-7652.2006.00208.x

Datta, S., Tiwari, S., Kaashyap, M., Gupta, P. P., Choudhury, P. R., Kumari, J., et al. (2011). Genetic similarity analysis in Lentil using cross-genera legume sequence tagged Microsatellite site markers. Crop Sci. 51, 2412-2422. doi: 10.2135/cropsci2010.12.0743

de la Puente, R., Garcia, P., Polanco, C., and Perez de la Vega, M. (2013). An improved intersubspecific genetic map in Lens including functional markers. Span. J. Agric. Res. 11, 132-136. doi: 10.5424/sjar/2013111-3283

D’Erfurth, I., Le Signor, C., Aubert, G., Sanchez, M., Vernoud, V., Darchy, B., et al. (2012). A role for an endosperm-localized subtilase in the control of seed size in legumes. New Phytol. 196, 738-751. doi: 10.1111/j.1469-8137.2012.04296

Duran, Y., Fratini, R., Garcia, P., and Pérez de la Vega, M. (2004). An intersubspecific genetic map of Lens. Theor. Appl. Genet. 108, 1265-1273. doi: 10.1007/s00122003-1542-3

Eujayl, I., Baum, M., Powell, W., Erskine, W., and Pehu, E. (1998a). A genetic linkage map of lentil (Lens sp.) based on RAPD and AFLP markers using recombinant inbred lines. Theor. Appl. Genet. 97, 83-89. doi: 10.1007/s001220050869

Eujayl, I., Erskine, W., Bayaa, B., Baum, M., and Pehu, E. (1998b). Fusarium vascular wilt in lentil: inheritance and identification of DNA markers for resistance. Plant Breed. 117, 497-499. doi: 10.1111/j.1439-0523.1998.tb01982.x

FAOSTAT. (2014). Available at: http://faostat3.fao.org/browse/Q/QC/E [accessed on January 12, 2015].

Fedoruk, M. J., Vandenberg, A., and Bett, K. E. (2013). Quantitative trait loci analysis of seed quality characteristics in lentil using single nucleotide polymorphism markers. Plant Genome 6, 37-39. doi: 10.3835/plantgenome2013.05.0012 
Ford, R., Pang, E. C. K., and Taylor, P. W. J. (1997). Diversity analysis and species identification in Lens using PCR generated markers. Euphytica 96, 247-255. doi: 10.1023/a:1003097600701

Ford, R., Pang, E. C. K., and Taylor, P. W. J. (1999). Genetics of resistance to ascochyta blight (Ascochyta lentis) of lentil and the identification of closely linked RAPD markers. Theor. Appl. Genet. 98, 93-98. doi: 10.1007/s001220051044

Ford, R., Viret, L., Pang, E. C. K., Taylor, P. W. J., Materne, M., and Mustafa, B. (2007). "Defense responses in lentil to Ascochyta lentis," in Proceedings of the Australian Plant Pathology Conference (Adelaide, SA: Australian Plant Pathology Society), 64.

Fratini, R., Duran, Y., Garcia, P., and Pérez de la Vega, M. (2007). Identification of quantitative trait loci (QTL) for plant structure, growth habit and yield in lentil. Span. J. Agric. Res. 5, 348-356. doi: 10.5424/sjar/2007053-255

Fratini, R., and Ruiz, M. L. (2003). A rooting procedure for lentil (Lens culinaris Medik.) and other hypogeous legumes (pea, chickpea and lathyrus) based on explant polarity. Plant Cell Rep. 21, 726-732. doi: 10.1007/s00299-00 3-0603-z

Fratini, R., Ruiz, M. L., and Pérez de la Vega, M. (2004). Intra-specific and inter-subspecific crossing in lentil (Lens culinaris Medik.). Can. J. Plant Sci. 84, 981-986. doi: 10.4141/p03-201

Furman, B. J. (2006). Methodology to establish a composite collection: case study in lentil. Plant Genetic Resour. 4, 2-12. doi: 10.1079/PGR200599

Gulati, A., Schryer, P., and McHughen, A. (2002). Production of fertile transgenic lentil (Lens culinaris Medik) plants using particle bombardment. In Vitro Cell. Dev. Biol. Plant 38, 316-324. doi: 10.1079/ivp2002303

Gupta, D., Taylor, P. W. J., Inder, P., Phan, H. T. T., Ellwood, S. R., Mathur, P. N., et al. (2012a). Integration of EST-SSR markers of Medicago truncatula into intraspecific linkage map of lentil and identification of QTL conferring resistance to ascochyta blight at seedling and pod stages. Mol. Breed. 30, 429-439. doi: 10.1007/s11032011-9634-2

Gupta, M., Verma, B., Kumar, N., Chahota, R. K., Rathour, R., Sharma, S. K., et al. (2012b). Construction of intersubspecific molecular genetic map of lentil based on ISSR, RAPD and SSR markers. J. Genet. 91, 279-287. doi: 10.1007/s12041012-0180-4

Hamwieh, A., Udupa, S., Choumane, W., Sarker, A., Dreyer, F., Jung, C., et al. (2005). A genetic linkage map of Lens sp. based on microsatellite and AFLP markers and the localization of fusarium vascular wilt resistance. Theor. Appl. Genet. 110, 669-677. doi: 10.1007/s00122-004-1892-5

Hamwieh, A., Udupa, S. M., Sarker, A., Jung, C., and Baum, M. (2009). Development of new microsatellite markers and their application in the analysis of genetic diversity in lentils. Breed. Sci. 59, 77-86. doi: 10.1270/jsbbs.59.77

Havey, M. J., and Muehlbauer, F. J. (1989). Linkages between restriction fragment length, isozyme and morphological markers in lentil. Theor. Appl. Genet. 77, 395-401. doi: 10.1007/bf00305835

Kahraman, A., Demirel, U., Ozden, M., and Muehlbauer, F. J. (2010). Mapping of QTLs for leaf area and the association with winter hardiness in fall-sown lentil. Afr. J. Biotechnol. 9, 8515-8519.

Kahraman, A., Kusmenoglu, I., Aydin, N., Aydogan, A., Erskine, W., and Muehlbauer F. J. (2004). QTL mapping of winter hardiness genes in lentil. Crop Sci. 44, 13-22. doi: $10.2135 /$ cropsci2004.0013

Kaur, S., Cogan, N. I., Stephens, A., Noy, D., Butsch, M., Forster, J., et al. (2014). EST-SNP discovery and dense genetic mapping in lentil (Lens culinaris Medik.) enable candidate gene selection for boron tolerance. Theor. Appl. Genet. 127, 703-713. doi: 10.1007/s00122-013-2252-0

Kaur, S., Cogan, N. O. I., Pembleton, L. W., Shinozuka, M., Savin, K. W., Materne, M., et al. (2011). Transcriptome sequencing of lentil based on second-generation technology permits large-scale unigene assembly and SSR marker discovery. BMC Genomics 12:265. doi: 10.1186/1471-2164-12-265

Khatib, F., Koudsieh, S., Ghazal, B., Barton, J., Tsujimoto, H., and Baum, M. (2007). Developing herbicide resistant lentil (Lens culinaris Medikus subsp. culinaris) through Agrobacterium-mediated transformation. Arab. J. Plant Protect. 25, 185192.

Khatib, F., Makris, A., Yamaguchi-Shinozaki, K., Kumar, S., Sarker, A., Erskine, W., et al. (2011). Expression of the DREB1A gene in lentil (Lens culinaris Medik. subsp culinaris) transformed with the Agrobacterium system. Crop Pasture Sci. 62 , 488-495. doi: 10.1071/cp10351

Khawar, K. M., and Özcan, S. (2002). Effect of indole-3-butyric acid on in vitro root development in lentil (Lens culinaris Medik.). Turk. J. Bot. 26, 109-111.
Kota, R., Rudd, S., Facius, A., Kolesov, G., Thiel, T., Zhang, H., et al. (2003). Snipping polymorphisms from large EST collections in barley (Hordeum vulgare L.). Mol. Genet. Genomics 270, 24-33. doi: 10.1007/s00438-00 3-0891-6

Kumar, J., Pratap, A., Solanki, R. K., Gupta, D. S., Goyal, A., Chaturvedi, S. K., et al. (2011). Advances in genomics resources for improving food legume crops. J. Agril. Sci. 150, 289-318. doi: 10.1017/S0021859611000554

Kumar, S., and Ali, M. (2006). GE interaction and its breeding implications in pulses. Botanica 56, 31-36.

Kumar, S. K., Barpete, S., Kumar, J., Gupta, P., and Sarker, A. (2013). Global lentil production: constraints and strategies. SATSA Mukhapatra-Annu. Tech. Issue $17,1-13$.

Kumar, S., Hamweih, A., Manickavelu, A., Kumar, J., Sharma, T. R., and Baum, M. (2014). "Advances in lentil genomics", in Legumes in Omics Era, eds S. Gupta, N. Nadarajan, and D. S. Gupta (New York: Springer Science+Business Media), 111-130.

Lurquin, P. F., Cai, Z., Stiff, C. M., and Fuerst, E. P. (1998). Half-embryo cocultivation technique for estimating the susceptibility of pea (Pisum sativum L.) and lentil (Lens culinaris Medik.) cultivars to Agrobacterium tumefaciens. Mol. Biotechnol. 9, 175-179. doi: 10.1007/BF02760819

Mahmoudian, M., Yucel, M., and Oktem, H. A. (2002). Transformation of lentil (Lens culinaris M.) cotyledonary nodes by vacuum infiltration of Agrobacterium tumefaciens. Plant Mol. Biol. Rep. 20, 251-257. doi: 10.1007/bf027 82460

Mekonnen, F., Mekbib, F., Kumar, S., Ahmed, S., Chahota, R. K., Sharma, T. R., et al. (2014). Identification of molecular markers associated with rust resistance genes in lentil (Lens culinaris sub sp. culinaris). Can. J. Plant Prot. 2, 27-36.

Mobini, S. H., Lulsdorf, T., Warkentin, D., and Vanderberg, A. (2014). Plant growth regulators improve in vitro flowering and rapid generation advancement in lentil and faba bean. In Vitro Cell. Dev. Biol. Plant doi: 10.1007/s11627-0149647-8

Mohamed, M. F., Read, P. E., and Coyne, D. P. (1992). Plant regeneration from in vitro culture of embryonic axis explants in common and tepary beans. J. Am. Soc. Hort. Sci. 117, 332-336.

Mustafa, B. M., Coram, T. E., Pang, E. C. K., Taylor, P. W. J., and Ford, R. (2006). "Unraveling Ascochyta lentis resistance in lentil," in Proceedings of the Ascochyta 2006 Conference, 2nd-5th July, France.

NCBI. (2015). Available at: http://www.ncbi.nlm.nih.gov/nucest/?term=lentil [accessed on January 12, 2015].

Oktem, H., Mahmoudian, M., and Yucel, M. (1999). GUS gene delivery and expression in lentil cotyledonary nodes using particle bombardment. LENS Newslett. 26, 3-6.

Pandian, A., Ford, R., and Taylor, P. W. (2000). Transferability of sequence tagged microsatellite site (STMS) primers across four major pulses. Plant Mol. Biol. Rep. 18, 395-395. doi: 10.1007/BF02825069

Perez de la Vega, M., Fratini, R. M., and Muehlbauer, F. J. (2011). "Lentil," in Genetics, Genomic and Breeding of Cool Season Grain Legumes (Genetics, Genomics and Breeding in Crop Plants), eds M. Perez de la Vega, A. M. Torres, J. I. Cubero, and C. Kole (Boca Raton, FL: Science Pubs), 98-150.

Phan, H. T., Ellwood, S. R., Hane, J. K., Ford, R., Materne, M., and Oliver, R. P. (2007). Extensive macrosynteny between Medicago truncatula and Lens culinaris ssp. culinaris. Theor. Appl. Genet. 114, 549-558. doi: 10.1007/s00122-0060455-3

Polanco, M. C., Peláez, M. I., and Ruiz, M. L. (1988). Factors affecting callus and shoot formation from in vitro cultures of Lens culinaris Medik. Plant Cell Tiss. Org. Cult. 15, 175-182. doi: 10.1007/BF00035759

Polanco, M. C., and Ruiz, M. L. (2001). Factors that affect plant regeneration from in vitro culture of immature seeds in four lentil cultivars. Plant Cell Tiss. Org. Cult. 66, 133-139. doi: 10.1023/A:1010652818812

Reddy, M. R. K., Rathour, R., Kumar, N., Katoch, P., and Sharma, T. R. (2010). Cross-genera legume SSR markers for analysis of genetic diversity in Lens species. Plant Breed. 129, 514-518. doi: 10.1111/j.1439-0523.2009.01723.x

Rubeena, Ford, R., and Taylor, P. W. J. (2003). Construction of an intraspecific linkage map of lentil (Lens culinaris ssp. culinaris). Theor. Appl. Genet. 107, 910-916. doi: 10.1007/s00122-003-1326-9

Rubeena, A., Taylor, P. W. J., Ades, P. K., and Ford, R. (2006). QTL mapping of resistance in lentil (Lens culinaris ssp. culinaris) to ascochyta blight (Ascochyta lentis). Plant Breed. 125, 506-512. doi: 10.1111/j.1439-0523.2006.01259.x 
Saha, G. C., Sarker, A., Chen, W., Vandemark, G. J., and Muehlbauer, F. J. (2010a). Inheritance and linkage map positions of genes conferring resistance to stemphylium blight in lentil. Crop Sci. 50, 1831-1839. doi: 10.2135/cropsci2009.12.0709

Saha, G. C., Sarker, A., Chen, W. D., Vandemark, G. J., and Muehlbauer, F. J. (2010b). Identification of markers associated with genes for rust resistance in Lens culinari Medik. Euphytica 175, 261-265. doi: 10.1007/s10681-010-0187-y

Saha, G. C., Sarker, A., Chen, W., Vandemark, G. J., and Muehlbauer, F. J. (2013). Inheritance and linkage map positions of genes conferring agromorphological traits in Lens culinaris Medik. Int. J. Agron. 2013, 9. doi: 10.1155/2013/6 18926

Sarker, R., Mustafa, B. M., Biswas, A., Mahbub, S., Nahar, M., Hashem, R., et al. (2003). In vitro regeneration in lentil (Lens culinaris Medik.). Plant Tissue Cult. $13,155-163$.

Sever, T., Ates, D., Aldemir, S. B., Yagmur, B., Kaya, H. B., Temel, H. Y., et al. (2014). "Identification QTLs controlling genes to se uptake in lentil seeds," in Proceedings of the Plant and Animal Genome XXII Conference, San Diego, CA.

Sharma, S. K., Dawson, I. K., and Waugh, R. (1995). Relationships among cultivated and wild lentils revealed by rapd analysis. Theor. Appl. Genet. 91, 647-654. doi: 10.1007/BF00223292

Sharma, S. K., Knox, M. R., and Ellis, T. H. N. (1996). AFLP analysis of the diversity and phylogeny of Lens and its comparison with RAPD analysis. Theor. Appl. Genet. 93, 751-758. doi: 10.1007/bf00224072

Sharpe, A. G., Ramsay, L., Sanderson, L. A., Fedoruk, M. J., Clarke, W. E., Rong, L., et al. (2013). Ancient orphan crop joins modern era: gene-based SNP discovery and mapping in lentil. BMC Genomics 14:192. doi: 10.1186/1471-2164 14-192

Simon, C. J., and Muehlbauer, F. J. (1997). Construction of a chickpea linkage map and its comparison with maps of pea and lentil. J. Hered. 88, 115-119. doi: 10.1093/oxfordjournals.jhered.a023068

Singh, R., and Raghuvanshi, S. (1989). Plantlet regeneration from nodal segment and shoot tip derived explants of lentil. LENS Newslett. 16, 33-35.

Solanki, R., Singh, S., and Kumar, J. (2010). Molecular marker assisted testing of hybridity of F1 plants in lentil. Food Legumes 23, 21-24.

Srivastava, R. P., and Vasishtha, H. (2012). Saponins and lectins of Indian chickpeas (Cicer arietinum) and lentils (Lens culinaris). Indian J. Agric. Biochem. 25, $44-47$.

Tadmor, Y., Zamir, D., and Ladizinsky, G. (1987). Genetic mapping of an ancient translocation in the genus Lens. Theor. Appl. Genet. 73, 883-892. doi: $10.1007 / \mathrm{bf00289394}$

Tahir, M., and Muehlbauer, F. J. (1994). Gene-mapping in lentil with recombinant inbred lines. J. Hered. 85, 306-310.

Tanyolac, B., Ozatay, S., Kahraman, A., and Muehlbauer, F. (2010). Linkage mapping of lentil (Lens culinaris L.) genome using recombinant inbred lines revealed by AFLP, ISSR, RAPD and some morphologic markers. J. Agric. Biotechnol. Sustain. Dev. 2, 1-6.

Taran, B., Buchwaldt, L., Tullu, A., Banniza, S., Warkentin, T. D., and Vandenberg, A. (2003). Using molecular markers to pyramid genes for resistance to ascochyta blight and anthracnose in lentil (Lens culinaris Medik.). Euphytica. 134, 223-230. doi: 10.1023/B:EUPH.0000003913.39616.fd

Temel, H. Y., Gol, D., Kahriman, A., and Tanyolac, M. B. (2014). Single nucleotide polymorphism discovery through Illumina- based transcriptome sequencing and mapping in lentil. Turk. J. Agric. For. 38, 1-19. doi: 10.3906/tar-1409-70

Thiel, T., Michalek, W., Varshney, R., and Graner, A. (2003). Exploiting EST databases for the development and characterization of gene-derived SSR-markers in barley (Hordeum vulgare L.). Theor. Appl. Genet. 106, 411-422.

Tullu, A., Buchwaldt, L., Warkentin, T., Taran, B., and Vandenberg, A. (2003). Genetics of resistance to anthracnose and identification of AFLP and RAPD markers linked to the resistance gene in PI 320937 germplasm of lentil (Lens culinaris Medikus). Theor. Appl. Genet. 106, 428-434.

Tullu, A., Tar'an, B., Breitkreutz, C., Buchwaidt, L., Banniza, S., Warkentin, T. D., et al. (2006). A quantitative-trait locus for resistance to ascochyta blight Ascochyta lentis maps close to a gene for resistance to anthracnose Colletotrichum truncatum in lentil. Can. J. Plant Pathol. 28, 588-595. doi: 10.1080/07060660609507337

Tullu, A., Tar'an, B., Warkentin, T., and Vandenberg, A. (2008). Construction of an Intraspecific linkage map and QTL analysis for earliness and plant height in lentil. Crop Sci. 48, 2254-2264. doi: 10.2135/cropsci2007.11.0628

Vandenberg, A. (2009). "Lentil expansion in Canada," in Milestones in Legume Research, eds M. Ali and S. Kumar (Kanpur: Indian Institute of Pulses Research), $58-72$.

Varshney, R. K., Graner, A., and Sorrells, M. E. (2005). Genic microsatellite markers in plants: features and applications. Trends Biotechnol. 23, 48-55. doi: 10.1016/j.tibtech.2004.11.005

Verma, P., Shah, N., and Bhatia, S. (2013). Development of an expressed gene catalogue and molecular markers from the de novo assembly of short sequence reads of the lentil (Lens culinaris Medik.) transcriptome. Plant Biotechnol. J. 11, 894-905. doi: 10.1111/pbi.12082

Verma, P., Sharma, T. R., Srivastava, P. S., Abdin, M. Z., and Bhatia, S. (2014). Exploring genetic variability within lentil (Lens culinaris Medik.) and across related legumes using a newly developed set of microsatellite markers. Mol. Biol. Rep. 41, 5607-5625. doi: 10.1007/s11033-014-3431-Z

Vijayan, P., Vandenberg, A., and Bett, K. E. (2009). A Mixed Genotype Lentil EST Library Representing the Normalized Transcriptome of Different Seed Development Stages. Available at: http://www.ncbi.nlm.nih.gov/nucest/?term=lens $\% 20$ culinaris Warkentin, T. D., and McHughen, A. (1992). Agrobacterium tumefaciens-mediated beta-glucuronidase (GUS) gene expression in lentil (Lens culinaris Medik.) tissues. Plant Cell Rep. 11, 274-278.

Weeden, N. F., Muehlbauer, F. J., and Ladizinsky, G. (1992). Extensive conservation of linkage relationships between pea and lentil genetic maps. J. Hered. 83, 123129

Weller, J. L., Liew, L. C., Hecht, V. F. G., Rajandran, V., Laurie, R. E., Ridge, S., et al. (2012). A conserved molecular basis for photoperiod adaptation in two temperate legumes. Proc. Natl. Acad. Sci. U.S.A. 109, 21158-21163. doi: $10.1073 /$ pnas. 1207943110

Williams, D. J., and McHughen, A. (1986). Plant regeneration of the legume Lens culinaris Medik. (lentil) in vitro. Plant Cell Tiss. Org. Cult. 7, 149-153. doi: 10.1007/BF00043039

Yaish, M. W., Saenz de Miera, L. E., and Perez de La Vega, M. (2004). Isolation of a family of resistance gene analogue sequences of the nucleotide binding site (NBS) type from Lens species. Genome 47, 650-659. doi: 10.1139/ g04-027

Zamir, D., and Ladizinsky, G. (1984). Genetics of allozyme variants and linkage groups in lentil. Euphytica 33, 329-336. doi: 10.1007/bf00021129

Zhu, H., Choi, H. K., Cook, D. R., and Shoemaker, R. C. (2005). Bridging model and crop legumes through comparative genomics. Plant Physiol. 137, 1189-1196. doi: 10.1104/pp.104.058891

Conflict of Interest Statement: The authors declare that the research was conducted in the absence of any commercial or financial relationships that could be construed as a potential conflict of interest.

Received: 31 October 2014; accepted: 30 January 2015; published online: 23 February 2015.

Citation: Kumar S, Rajendran K, Kumar J, Hamwieh A and Baum M (2015) Current knowledge in lentil genomics and its application for crop improvement. Front. Plant Sci. 6:78. doi: 10.3389/fpls.2015.00078

This article was submitted to Plant Genetics and Genomics, a section of the journal Frontiers in Plant Science.

Copyright (c) 2015 Kumar, Rajendran, Kumar, Hamwieh and Baum. This is an openaccess article distributed under the terms of the Creative Commons Attribution License (CC BY). The use, distribution or reproduction in other forums is permitted, provided the original author(s) or licensor are credited and that the original publication in this journal is cited, in accordance with accepted academic practice. No use, distribution or reproduction is permitted which does not comply with these terms. 